\title{
SMOKING TOBACCO, USE OF MARIJUANA AND OTHER PSYCHOACTIVE SUBSTANCES BY STUDENTS OF SILESIAN UNIVERSITIES
}

\author{
PALENIE TYTONIU, UŻYWANIE MARIHUANY I INNYCH SUBSTANCJI \\ PSYCHOAKTYWNYCH PRZEZ STUDENTÓW ŚLĄSKICH UCZELNI
}

\author{
Medical University of Silesia, Faculty of Pharmaceutical Science Department of Toxicology \\ and Bioanalysis, Sosnowiec, Poland \\ Śląski Uniwersytet Medyczny, Wydział Nauk Farmaceutycznych Katedra i Zakład Toksykologii \\ i Bioanalizy, Sosnowiec, Polska
}

\begin{abstract}
INTRODUCTION. These days, it is observed worldwide that the number of smokers drops, however, use of e-cigarettes and other psychoactive substances becomes more popular. This survey was conducted in the years 2019 to 2020 using a group of 193 people, 124 females and 69 males, at two Silesian universities.

AIM. The purpose of this survey was to estimate patterns concerning use of tobacco and psychoactive substances by students. The survey was conducted by a survey including 27 questions.

RESULTS. Most of the surveyed persons (78\%) were non-smokers. Among active smokers, $30 \%$ of them started smoking at the age of 12 to $15,45 \%$ of them at 16 to 18 , and $77 \%$ smoked first before 18 th birthday. Among smoking subjects, $90 \%$ smokes up to 5 cigarettes a day. Most subjects replied that "curiosity" was a cause to start smoking. Students often declared so-called "occasional smoking”. Smoking in public bothered most (67\%) subjects. Half of subjects declared that they never smoked marijuana. Mostly, students smoking tobacco decided to use marijuana as well. About $6 \%$ of subjects used other drugs, aside from marijuana. $3 \%$ of subjects tried amphetamine, LSD or ecstasy at least once in life.

COCLUSIONS. Tobacco smoking frequency in students of Silesian universities was $22 \%$, that is a level similar to other regions of Poland. Due to variation on the market of psychoactive substances, particularly among young people, continuous surveillance is recommended.
\end{abstract}

Key words: students, tobacco smoking, marijuana, psychoactive substances

\section{STRESZCZENIE}

WSTĘP. Obecnie obserwuje się światowy trend spadku liczby osób palących, jednak wzrasta popularność użycia e-papierosów oraz innych środków psychoaktywnych. Badanie przeprowadzono w latach 2019-2020 na grupie 193 osób, 124 kobiet i 69 mężczyzn, 2 śląskich uniwersytetów.

CEL PRACY. Celem badań było oszacowanie palenia tytoniu oraz stosowania substancji psychoaktywnych wśród studentów. Badanie zostało przeprowadzone z wykorzystaniem ankiety składającej się z 27 pytań.

WYNIKI. Większość badanych (78\%) stanowiły osoby niepalące. Spośród osób obecnie palących 30\% zaczęło palić w wieku $12-15$ lat, $45 \% \mathrm{w}$ wieku $16-18$ lat, a $77 \%$ po raz pierwszy zapaliła papierosa przed ukończeniem 18 r.ż. Pośród badanych palących $90 \%$ wypala do 5 papierosów dziennie. Jako powód do zainicjowania palenia ankietowani najczęściej wymieniali „ciekawość”. Studenci często deklarują tzw. „palenie okazjonalne”. Palenie w miejscach publicznych przeszkadza większości (67\%) ankietowanych. Połowa badanych studentów deklarowała, że nigdy nie paliła marihuany. Po marihuanę sięgali głównie studenci palący papierosy. Około 6\% ogółu ankietowanych poza marihuaną używało także innych narkotyków. 3\% ogółu ankietowanych przynajmniej raz w życiu używało amfetaminy, LSD lub ekstazy.

(C) National Institute of Public Health - National Institute of Hygiene / Narodowy Instytut Zdrowia Publicznego - Państwowy Zakład Higieny 
WNIOSKI. Częstość palenia tytoniu wśród studentów śląskich uczelni wynosiła $22 \%$ i była na podobnym poziomie w porównaniu ze studentami innych rejonów Polski. Ze względu na zmienny rynek środków psychoaktywnych, szczególnie wśród młodych osób, wskazany jest ciągły monitoring zjawiska.

Słowa kluczowe: studenci, palenie tytoniu, marihuana, substancje psychoaktywne

\section{INTRODUCTION}

Tobacco smoking is one of the most important health-related problems faced by many countries. Smoking causes serious diseases such as heart disease, cancer - mainly lung cancer, respiratory infections, asthma, both in active and passive smokers (1-3). It is also a great burden for the economy due to high medical costs $(4,5)$. Addiction to tobacco has many aspects of a chronic disease, most patients fail to abstain after the first attempt to quit smoking, they have relapse periods, and often require multiple interventions to quit (6). The most important factor protecting against cigarette smoking is physical activity, while the main risk factor is frequent company of smokers (7). The negative effects of smoking on overall health have been documented well (1-3, 8-14). On average, smokers die ten years younger than non-smokers (15). Nicotine addiction often coexists with alcohol consumption (16).

Global organizations (WHO, UE) implement many procedures to reduce tobacco consumption, including taking menthol cigarettes off the market. Global smoking is expected to decline to around $16 \%$ of the total population by 2030. Rich countries spend large amounts of money on campaigns aimed at quitting smoking (17). Education in the field of harmfulness and negative effects of smoking should be spread among children from the first years of education (18). People who start smoking in adolescence usually remain addicted to smoking for a period of 15-20 years (19).

The universality of tobacco use in Europe varies widely - in Western countries smoking rates are below $25 \%$ of the population, and in Eastern countries it is generally above $30 \%$ (20).

Currently, there is a peculiar e-cigarette epidemic in the USA. There is an almost snowballing rise in the use of these products among American high school students, resulting in enormous nicotine addiction (21).

In Poland, in 2019, 30\% of adolescents aged 15-16 used e-cigarettes, and 9\% cannabis-derived products (22). In surveys, the adolescents inform that they know the toxic effects of the substances they take but the knowledge is very cursory and general, and it does not focus on the mechanisms of toxic action and the formation of addiction (23).

Cannabis is the most widely used drug in all age groups. It is most often smoked directly and blended with tobacco. It is estimated that 91.2 million people in the European Union (aged 15-64), i.e. $27.4 \%$ of the

\section{WPROWADZENIE}

Jednym $\mathrm{z}$ najważniejszych problemów zdrowotnych, z jakim boryka się wiele krajów jest palenie tytoniu. Palenie powoduje poważne choroby takie jak: choroby serca, nowotwory - głównie rak płuc, infekcje dróg oddechowych, astmę, zarówno u aktywnych, jak i biernych palaczy (1-3). Stanowi także obciążenie dla gospodarki ze względu na duże koszty medyczne $(4,5)$. Uzależnienie od tytoniu ma wiele aspektów choroby przewlekłej, większość pacjentów nie osiąga abstynencji po pierwszej próbie rzucenia palenia, mają okresy nawrotu i często wymagają wielokrotnych interwencji w rzucaniu palenia (6). Najważniejszym czynnikiem chroniącym przed paleniem papierosów jest aktywność fizyczna, natomiast głównym czynnikiem ryzyka jest częste przebywanie w towarzystwie osób palących (7). Negatywne skutki palenia tytoniu dla ogólnego stanu zdrowia są dobrze udokumentowane (1-3, 8-14). Przeciętnie palacze umierają o dziesięć lat młodsi niż osoby niepalące (15). Uzależnienie od nikotyny często współistnieje ze spożywaniem alkoholu (16).

Światowe organizacje (WHO, UE) wdrażają wiele procedur mających na celu ograniczenie palenia tytoniu, m.in. wycofanie papierosów mentolowych. Oczekuje się, że do 2030 roku palenie tytoniu zmniejszy się globalnie do około 16\% ogółu populacji. Bogate państwa przeznaczają duże nakłady finansowe na programy promujące zaprzestanie palenia tytoniu (17). Edukacja w zakresie szkodliwości i negatywnych skutków palenia powinna być rozpowszechniana wśród dzieci od pierwszych lat nauczania (18). Osoby rozpoczynające palenie w okresie dorastania trwają zwykle w nałogu przez okres 15-20 lat (19).

Powszechność używania tytoniu w Europie jest zróżnicowana - w krajach zachodnich wskaźnik palenia wynosi poniżej $25 \%$ populacji, a w krajach wschodnich na ogół przekracza 30\% (20). Obecnie w USA występuje swoista epidemia e-papierosów. Obserwuje się niemal lawinowy wzrost używania tych produktów wśród amerykańskich uczniów szkół średnich, co skutkuje olbrzymim uzależnieniem od nikotyny (21).

W Polsce w 2019 r. 30\% nastolatków w wieku 1516 lat używało e-papierosów, a 9\% produktów pochodnych konopi (22). Młodzież w ankietach informuje, że zna działanie toksyczne zażywanych substancji, jednak jest to wiedza bardzo pobieżna i ogólna, nieskupiająca się na mechanizmach działania toksycznego oraz powstawania uzależnienia (23). 
population, have experimented with cannabis products at least once in their lifetime, and $14.4 \%$ of this group have used cannabis throughout the last year. Throughout the last year, the use of this drug in Europe ranged from $3.5 \%$ in Hungary to $21.8 \%$ in France (24). When taking into account only the 15-24 age group, the prevalence of cannabis use in Europe is higher: $18 \%$ of people $(10.1$ $\mathrm{mln}$ ) took this drug throughout the last year, and 9.3\% $(5.2 \mathrm{mln})$ throughout the last month. In most European countries, survey results show that last year levels of cannabis use are stable, while 11 countries (e.g. Ireland, Finland) reported an increase in use in the 15-24 age group in the survey (24).

\section{AIM}

The aim of the study was to collect and compare data on smoking tobacco and marijuana, and the use of other psychoactive substances among students of two faculties of two Silesian universities. The research aimed at showing whether there is a difference in the frequency of smoking and consumption of psychoactive substances among students of medical (Medical University of Silesia) and non-medical (University of Economics) universities, and whether knowledge of the consequences and risks of using these products affects their use. Research questions concerned the age at which people first used drugs, circumstances conducive to the formation of addiction, the amount of substances used, and the knowledge of the consequences and risks to health.

\section{MATERIALS AND METHODS}

The research was conducted in 2019-2020. It covered a group of 193 people, 124 women and 69 men, students of finance and accounting at the College of Finance of the University of Economics in Katowice (EU) $(n=91)$, and pharmacy at the Faculty of Pharmaceutical Sciences of the Medical University of Silesia in Katowice (SUM) $(n=102)$. The age of the studied people was 19-26 years. Most of the students lived in the province of Silesia, mainly in medium-sized cities with 10-200 thousand residents ( $47 \%$ of the population), $30 \%$ of the respondents were rural residents, $14 \%$ of large cities over 200,000 inhabitants (Table I.).

The subject of the research was a survey prepared by the author, consisting of 27 questions about smoking tobacco, marijuana, and taking other drugs. The survey questions and answers are presented in Tables II and III. Participation in the study was voluntary, anonymous and confidential. All students consented to participate and were allowed to stop or refuse to answer any question at any time without giving any reason.
Konopie indyjskie są najpowszechniej używanym narkotykiem we wszystkich grupach wiekowych. Najczęściej są one palone bezpośrednio oraz mieszane z tytoniem. Szacuje się, że 91,2 mln osób w Unii Europejskiej (między 15 a 64 r.ż.), tj. 27,4\% populacji przynajmniej raz w życiu eksperymentowało z produktami pochodzącymi z konopi, a $14,4 \%$ tej grupy używało konopi indyjskich w ciągu ostatniego roku. Wskaźnik używania tego narkotyku w Europie w ciągu ostatniego roku waha się od 3,5\% na Węgrzech do 21,8 \% we Francji (24). Gdy bierze się pod uwagę wyłącznie grupę wiekową 15-24 lata, rozpowszechnienie używania konopi indyjskich w Europie jest wyższe: 18\% osób (10,1 mln) zażywało ten narkotyk w ciągu ostatniego roku, a 9,3\% $(5,2 \mathrm{mln}) \mathrm{w}$ ciągu ostatniego miesiąca. W większości państw europejskich wyniki badań ankietowych pokazują, że poziom używania konopi indyjskich w ciągu ostatniego roku jest stały, natomiast 11 państw (np. Irlandia, Finlandia) w badaniu odnotowało wzrost używania w grupie wiekowej 15-24 lata (24).

\section{CEL PRACY}

Celem pracy było zebranie i porównanie danych na temat palenia tytoniu, marihuany oraz zażywania innych substancji psychoaktywnych wśród studentów dwóch kierunków dwóch śląskich uniwersytetów. Badania miały pokazać, czy istnieje różnica $\mathrm{w}$ częstości palenia tytoniu i spożywania substancji psychoaktywnych pośród studentów uczelni medycznej (Śląski Uniwersytet Medyczny) oraz niemedycznej (Uniwersytet Ekonomiczny) oraz czy wiedza na temat konsekwencji i zagrożeń z powodu używania tych produktów ma wpływ na ich zażywanie. Pytania badawcze dotyczyły określenia wieku, w którym osoby pierwszorazowo sięgały po używki, okoliczności sprzyjających powstaniu nałogu, ilości stosowanych substancji oraz wiedzy na temat konsekwencji i zagrożeń dla zdrowia.

\section{MATERIAŁ I METODY}

Badanie przeprowadzono w latach 2019-2020. Objęto nim grupę 193 osób, 124 kobiety i 69 mężczyzn, studentów kierunku finanse i rachunkowość Kolegium Finansów Uniwersytetu Ekonomicznego w Katowicach (UE) $(n=91)$ i kierunku farmacja Wydziału Nauk Farmaceutycznych Śląskiego Uniwersytetu Medycznego w Katowicach (SUM) $(n=102)$. Wiek badanych osób wynosił 19-26 lat. Studenci w większości mieszkali na terenie woj. śląskiego, głównie w średnich miastach, liczących $10-200$ tys. mieszkańców (47\% populacji), 30\% badanych było mieszkańcami wsi, 14\% dużych miast powyżej 200 tyś mieszkańców (Tab. I.)

Przedmiotem badań była autorska ankieta składająca się z 27 pytań dotyczących palenia papierosów, ma- 
Table I. Characteristics of the studied group

Tabela I. Charakterystyka grupy badanej

\begin{tabular}{|c|c|c|c|c|}
\hline \multicolumn{3}{|c|}{ Characteristics of the studied group } & \multirow{2}{*}{$\begin{array}{c}\mathrm{N} \\
193\end{array}$} & \multirow{2}{*}{$\begin{array}{c}\begin{array}{c}\text { Arithmetic } \\
\text { mean }\end{array} \\
(\min -\max ) \\
20.9(19-26)\end{array}$} \\
\hline \multirow{5}{*}{ Age } & \multicolumn{2}{|c|}{ total } & & \\
\hline & \multirow{2}{*}{ gender } & men & 69 & $20.5(19-26)$ \\
\hline & & women & 124 & $21.1(19-26)$ \\
\hline & \multirow{2}{*}{ students } & UE & 91 & $19.3(19-22)$ \\
\hline & & SUM & 102 & $22.2(21-26)$ \\
\hline \multirow{4}{*}{ Place of residence } & \multicolumn{2}{|c|}{ big city } & 27 & \\
\hline & \multicolumn{2}{|c|}{ medium-sized city } & 91 & \\
\hline & \multicolumn{2}{|c|}{ small city } & 16 & \\
\hline & \multicolumn{2}{|c|}{ village } & 58 & \\
\hline
\end{tabular}

UE - students of finance and accounting, College of Finance at University of Economics in Katowice, SUM - students of pharmacy, Faculty of Pharmaceutical Science at Medical University of Silesia in Katowice.

The survey was verified by the Bioethics Committee, and the survey procedure was carried out in accordance with the requirements of the Medical University of Silesia. The surveys were made available to students during didactic classes at universities. The time limit was not specified, and the survey usually took students about 10 minutes to fill in.

The statistical analysis of the data was made using the Statistica Pl software. 13.1 Software. The dependences between qualitative features were tested with the $\chi^{2}$ test. With low numbers in the subgroup $(\mathrm{n}<5)$, the $\chi^{2}$ test with Yates correction was used. The results for which $\mathrm{p}<0.05$ were considered statistically significant.

\section{RESULTS}

According to the answers given, there were 150 non-smokers and 43 smokers in the entire study group $(n=193)$. The majority, i.e. $78 \%$ of the respondents were non-smokers. The percentage of male and female nonsmokers was similar, it was $79 \%$ and $77 \%$, respectively. A slightly higher percentage of non-smokers was recorded among students of the medical faculty (SUM) - 79\%, compared to students of the economic faculty (EU), where $76 \%$ were non-smokers. Among the surveyed students, $22 \%$ described themselves as smokers ( $23 \%$ of men and $21 \%$ of women).

Table II presents the survey questions and answers given by students who smoke cigarettes. When asked about their first-time smoking, a slight majority of the respondents $(58 \%)$ replied that they had no contact with tobacco smoke at home. Their parents/guardians did not smoke. Early childhood exposure to passive smoking at home translated into active smoking slightly more often among female students rather than male students ( $44 \%$ vs. $38 \%)$. rihuany oraz spożywania innych narkotyków. Pytania ankietowe i odpowiedzi zostały przedstawione w tabelach II i III. Udział w badaniu był dobrowolny, anonimowy i poufny. Wszyscy studenci wyrazili zgodę na uczestnictwo i mogli w dowolnym momencie przerwać lub odmówić odpowiedzi na którekolwiek pytanie bez podawania powodu.

Kwestionariusz został zweryfikowany przez Komisję Bioetyczną, a procedura badania została przeprowadzona zgodnie z wymogami Śląskiego Uniwersytetu Medycznego. Ankiety były udostępniane studentom podczas zajęć dydaktycznych na uczelniach. Limit czasowy nie był określony, wypełnienie ankiety zazwyczaj zajmowało studentom ok. 10 min.

Analizę statystyczną danych przeprowadzono z wykorzystaniem programu Statistica Pl. 13.1 software (StatSoft, Cracow, Poland). Zależności pomiędzy cechami jakościowymi badano testem $\chi^{2}$. Przy niskiej liczebności w podgrupie $(\mathrm{n}<5)$ stosowano test $\chi^{2} \mathrm{z}$ poprawką Yatesa. Za istotne statystycznie przyjęto wyniki dla których $\mathrm{p}<0,05$.

\section{WYNIKI}

W świetle udzielonych odpowiedzi w całej grupie badanej ( $n=193)$ było 150 osób niepalących i 43 osoby palące. Większość, tj. 78\% ankietowanych stanowiły osoby niepalące. Odsetek niepalących mężczyzn i kobiet był zbliżony, wynosił odpowiednio $79 \%$ i $77 \%$. Nieznacznie większy odsetek niepalących zanotowano wśród studentów kierunku o profilu medycznym (SUM) - 79\% w porównaniu do studentów kierunku o profilu ekonomicznym (UE), gdzie niepalących było $76 \%$. Wśród ankietowanych studentów $22 \%$ określiło się jako osoby palące ( $23 \%$ mężczyzn i $21 \%$ kobiet).

W tabeli II przedstawiono pytania ankietowe i odpowiedzi udzielone przez studentów aktualnie palą- 
Among current smokers, the majority (77\%) had smoked a cigarette for the first time before the age of 18 . Within the age of $12-15,30 \%$ of the respondents began smoking, and within the age of $16-18-45 \%$. Single cases concern smoking before the age of $12.21 \%$ of people smoked their first cigarette in adulthood (over 18 years of age). The most common reasons for beginning to smoke were "curiosity" (75\%) and "for company" (23\%). 3\% of people started smoking at somebody's instigation. Smokers declare that they smoke up to 5 cigarettes a day ( $90 \%$ of the group) and 6-15 cigarettes ( $8 \%$ of the group) (Fig. 1.).

The students mainly declare the so-called "occasional smoking". This method of smoking is more often practised by women (52\%) than by men (31\%). A favourable occasion to reach for a cigarette are primarily social events (for $44 \%$ of the respondents), especially when accompanied by alcohol. Stressful situations and boredom are situations that also encourage smoking (Table II.). The surveyed students $100 \%$ were cych papierosy. W pytaniu o pierwszorazowy kontakt z paleniem, nieznaczna większość ankietowanych (58\%) odpowiedziała, że nie miała kontaktu z dymem tytoniowym w domu. Ich rodzice/opiekunowie nie palili papierosów. Wcześniejsze, mające miejsce w wieku dziecięcym, narażenie na bierne palenie w warunkach domowych nieco częściej przekładało się na czynne palenie studentek niż studentów ( $44 \%$ vs. $38 \%$ ).

Spośród osób obecnie palących, większość (77\%), po raz pierwszy zapaliła papierosa przed ukończeniem 18 r.ż. W wieku $12-15$ lat zaczęło palić $30 \%$, a w wie$\mathrm{ku}$ 16-18 lat - 45\%. Jednostkowe przypadki dotyczą palenia przed ukończeniem 12 r.ż. W wieku dorosłym (powyżej 18 r.ż.) pierwszego papierosa wypaliło $21 \%$ osób. Jako powód do zainicjowania palenia ankietowani najczęściej wymieniali „ciekawość” (75\%) i „dla towarzystwa" (23\%). Za namową innych osób zaczęło palić $3 \%$ osób. Palący deklarują, że dziennie wypalają najczęściej do 5 sztuk papierosów (90\% grupy) oraz 6-15 papierosów (8\% grupy) (Ryc. 1.).

Fig. 1. Tobacco smoking by the students of Silesian universities.

Ryc. 1. Palenie papierosów przez studentów śląskich uniwersytetów.

When did you start smoking? (age)

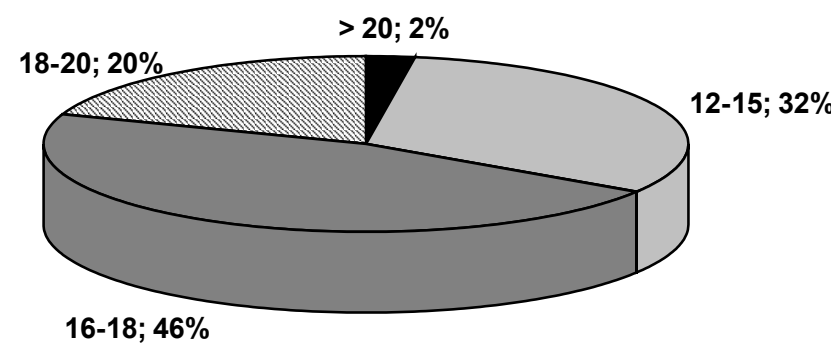

How many cigarettes do you smoke per day?

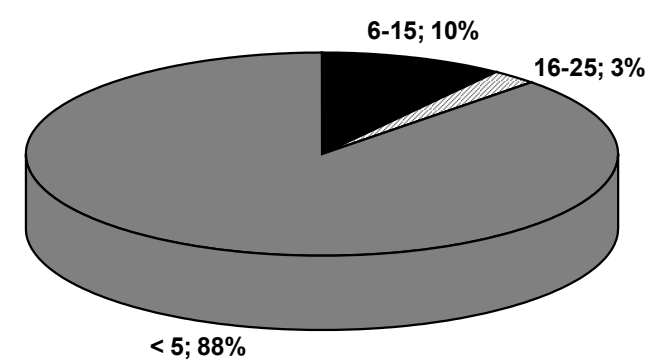

What did you start smoking? (the reason)

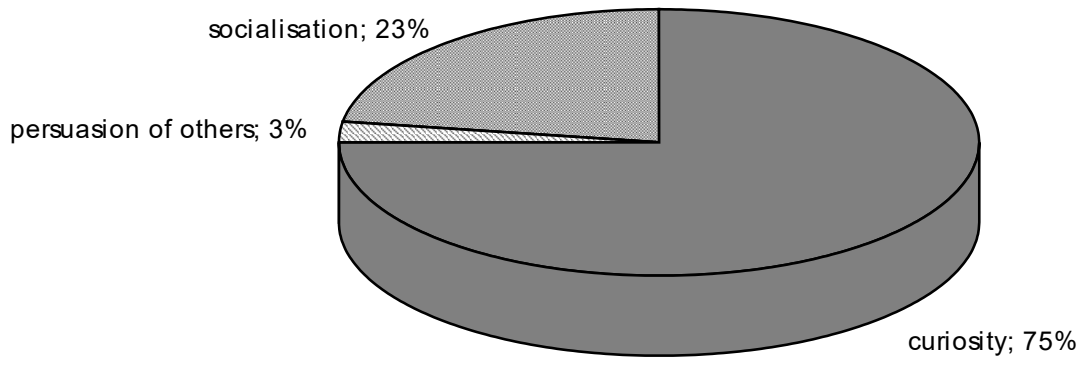

aware of the health consequences of heavy smoking. According to the majority of smokers, the process of lung regeneration after quitting the addiction is long, it is about 5 years or more (over 10 years). $65 \%$ of the surveyed smoking population want to quit smoking. $74 \%$ of women and $50 \%$ of men have such plans (Table II.).
Studenci głównie deklarują tzw. „palenie okazjonalne". Częściej taki sposób palenia praktykują kobiety (52\%) niż mężczyźni (31\%). Sprzyjającą okazją do sięgnięcia po papierosa są przede wszystkim imprezy towarzyskie (dla $44 \%$ badanych), zwłaszcza gdy towarzyszy im alkohol. Stresujące sytuacje i znudzenie to sytuacje, które także zachęcają do zapalenia papierosa (Tab. II.). Ankietowani studenci w $100 \%$ byli świadomi 
Table II. Survey questions and positive answers by subjects (students of UE and SUM), smokers Tabela II. Pytania ankietowe i twierdzące odpowiedzi grupy badanej (studenci UE i SUM), osoby palące

\begin{tabular}{|c|c|c|c|c|}
\hline \multirow{2}{*}{\multicolumn{2}{|c|}{$\begin{array}{l}\text { Survey questions } \\
\text { Total }\end{array}$}} & \multicolumn{3}{|c|}{ YES answers, \% } \\
\hline & & Females & Males & \\
\hline \multicolumn{2}{|c|}{ Was there exposure to tobacco smoke at your household? } & 41.9 & 44.4 & 37.5 \\
\hline \multirow{5}{*}{$\begin{array}{c}\text { What is the reason you tried } \\
\text { cigarettes? }\end{array}$} & Stress & 25.6 & 29.6 & 18.8 \\
\hline & $\begin{array}{c}\text { Boredom / trying to pass the } \\
\text { time }\end{array}$ & 23.3 & 25.9 & 18.8 \\
\hline & Party or event & 44.2 & 51.9 & 31.3 \\
\hline & Socialisation & 30.2 & 33.3 & 25.0 \\
\hline & Pleasure & 20.9 & 22.2 & 18.8 \\
\hline \multicolumn{2}{|c|}{ Do you intend to quit smoking? } & 65.1 & 74.1 & 50.0 \\
\hline \multicolumn{2}{|c|}{ Are you aware of consequences of long-term smoking? } & 100 & 100 & 100 \\
\hline \multicolumn{2}{|c|}{ Are you aware of consequences of smoking in pregnant women? } & 97.7 & 100 & 93.8 \\
\hline \multirow{3}{*}{$\begin{array}{l}\text { Have you tried alternative } \\
\text { forms of nicotine? }\end{array}$} & Any & 32.6 & 44.4 & 12.5 \\
\hline & Electronic cigarettes & 32.6 & 44.4 & 12.5 \\
\hline & Water pipe & 20.9 & 18.5 & 25.0 \\
\hline
\end{tabular}

UE - students of finance and accounting, College of Finance at University of Economics in Katowice, SUM - students of pharmacy, Faculty of Pharmaceutical Science at Medical University of Silesia in Katowice.

$73 \%$ of all the respondents believe that passive smoking is just as harmful as active smoking. Nonsmokers are much more convinced about the negative effect of passive smoking than those who smoke (76\% vs. $44 \%$ ). $56 \%$ of smokers believe that passive smoking is less harmful than active smoking (Table III.). All smoking students are aware that smoking while pregnant has a detrimental effect on the fetus. $94 \%$ of men hold this view as well (Table II.).

Smoking in public places disturbs the majority (67\%) of the respondents; it disturbs non-smokers much more often than smokers ( $77 \%$ vs. $35 \%)$. For $18 \%$ of the surveyed population, smoking in public places is not an issue. This opinion is mostly shared by smokers $(33 \%)$ (Table III.).

In the survey, the students were asked about alternative forms of smoking. $33 \%$ of the smoking respondents, definitely more often women than men (44\% vs. $13 \%$ ), replied that they have used such forms in their lifetime. Electronic cigarettes and a water pipe were the most common alternatives to traditional tobacco smoking (Table II.).

Half (51\%) of all the surveyed students declared that they had never smoked marijuana. Mainly, marijuana was used by students who smoked cigarettes (about $80 \%$ ). The marijuana-exposed population most frequently reported using marijuana a few times (28\%), more than a few times (11\%), or just one time 7\% (Table III.).

$49 \%$ of the respondents believe that marijuana is a drug like alcohol or cigarettes, while $35 \%$ of the respondents say that it is a drug harmful like other drugs. $74 \%$ of all the respondents are aware of the legal consequences of possessing or trading marijuana in następstw zdrowotnych nałogowego palenia papierosów. Według większości ankietowanych palących proces regeneracji płuc po zaprzestaniu nałogu jest długotrwały - wynosi około 5 lat lub dłużej (powyżej 10 lat). $65 \%$ badanej populacji aktualnie palącej papierosy chce zerwać z nałogiem. Takie plany ma $74 \%$ kobiet i 50\% mężczyzn (Tab. II.).

$73 \%$ ogółu ankietowanych uważa, że bierne palenie jest tak samo szkodliwe jak czynne. Zdecydowanie częściej o negatywnym wpływie biernego palenia są przekonane osoby niepalące niż palące ( $76 \%$ vs $44 \%$ ). $56 \%$ palących jest zdania, że palenie bierne jest mniej szkodliwe niż aktywne (Tab. III.). Wszystkie palące studentki są świadome, że palenie w ciąży ma szkodliwy wpływ na płód. Taki pogląd podtrzymuje także $94 \%$ mężczyzn (Tab. II.).

Palenie w miejscach publicznych przeszkadza większości (67\%) ankietowanych, zdecydowanie częściej osobom niepalącym niż palącym (77\% vs. $35 \%)$. Dla $18 \%$ populacji ankietowanej palenie $\mathrm{w}$ miejscach publicznych jest obojętne. Takiego zdania są przede wszystkim palący (33\%) (Tab. III.).

$\mathrm{W}$ ankiecie zapytano studentów o alternatywne formy palenia tytoniu. 33\% palących badanych, zdecydowanie częściej kobiety niż mężczyźni (44\% vs. 13\%) odpowiadało, że korzystało z takich form. Najczęściej alternatywą do tradycyjnego palenia tytoniu były papierosy elektroniczne oraz fajka wodna (Tab. II.).

Połowa $(51 \%)$ spośród wszystkich badanych studentów deklarowała, że nigdy nie paliła marihuany. Głównie po marihuanę sięgali studenci palący papierosy (około $80 \%$ ). Populacja mająca kontakt $\mathrm{z}$ marihuaną najczęściej deklarowała, że używała marihuany kilka 
Table III. Survey questions and positive answers by subjects (students of UE and SUM)

Tabela III. Pytania ankietowe i odpowiedzi grupy badanej (studenci UE i SUM)

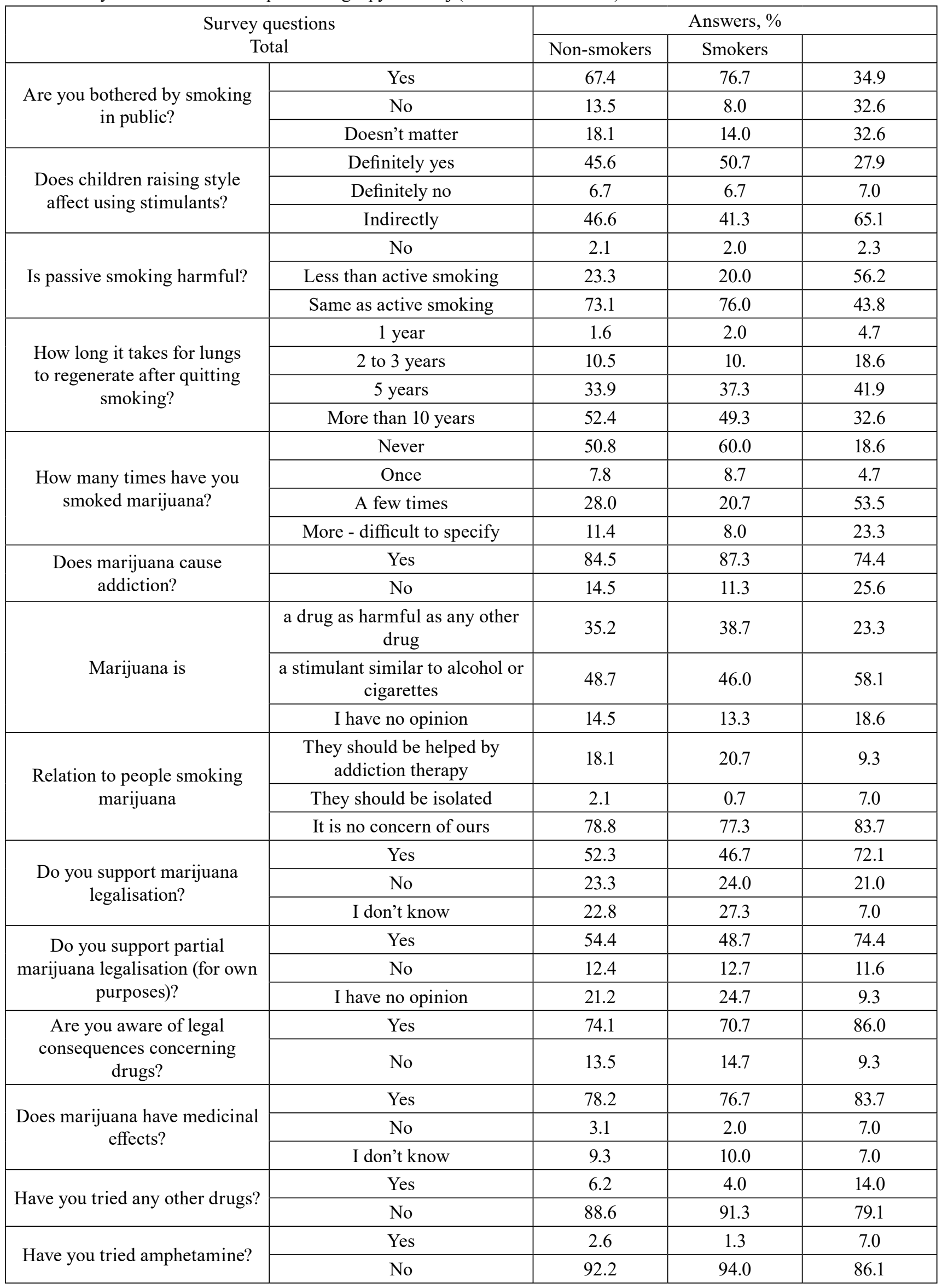




\begin{tabular}{|c|c|c|c|c|}
\hline \multirow{2}{*}{ Have you tried cocaine? } & Yes & 1.6 & 0.7 & 4.7 \\
\hline & No & 92.8 & 94.0 & 88.4 \\
\hline \multirow{2}{*}{ Have you tried LSD? } & Yes & 2.6 & 2.0 & 4.7 \\
\hline & No & 92.2 & 93.3 & 88.4 \\
\hline \multirow{2}{*}{ Have you tried ecstasy? } & Yes & 3.1 & 1.3 & 9.3 \\
\hline & No & 91.7 & 94.0 & 83.7 \\
\hline \multirow{2}{*}{$\begin{array}{l}\text { Have you tried designer drugs } \\
\text { (NPS)? }\end{array}$} & Yes & 0.5 & 0 & 2.3 \\
\hline & No & 94.3 & 95.3 & 90.7 \\
\hline \multirow{2}{*}{$\begin{array}{l}\text { Have you tried overdosing } \\
\text { medicines? }\end{array}$} & Yes & 1.5 & 1.3 & 2.3 \\
\hline & No & 93.3 & 94.0 & 90.7 \\
\hline \multirow{5}{*}{ Drugs are } & remedies to problems & 5.2 & 5.3 & 4.7 \\
\hline & a way to get cool & 20.7 & 10.7 & 32.6 \\
\hline & $\begin{array}{l}\text { a way to find myself in another } \\
\text { reality }\end{array}$ & 40.4 & 20.0 & 18.6 \\
\hline & a way to impress friends & 46.6 & 6.7 & 4.7 \\
\hline & trendy, such as cigarettes & 62.7 & 7.3 & 4.7 \\
\hline \multirow{2}{*}{$\begin{array}{l}\text { Does a single dose of drugs } \\
\text { cause addiction? }\end{array}$} & Yes & 57.5 & 60.0 & 48.8 \\
\hline & No & 41.0 & 38.0 & 51.2 \\
\hline \multirow{4}{*}{$\begin{array}{l}\text { According to you, how many } \\
\text { young people tried drugs? }\end{array}$} & $1-5 \%$ & 1.6 & 1.3 & 2.3 \\
\hline & $5-20 \%$ & 30.1 & 30.0 & 30.2 \\
\hline & $20-50 \%$ & 51.8 & 53.3 & 46.5 \\
\hline & More than $50 \%$ & 15.4 & 14.0 & 20.9 \\
\hline
\end{tabular}

UE - students of finance and accounting, College of Finance at University of Economics in Katowice, SUM - students of pharmacy, Faculty of Pharmaceutical Science at Medical University of Silesia in Katowice.

Poland. This awareness is higher among smokers than among non-smokers. More than half of the surveyed students $(52 \%)$ want marijuana to be legalized. Most of them are smokers ( $72 \%) .23 \%$ of the surveyed population do not support such activities or have no opinion on this subject. $12 \%$ of the respondents are against the partial legalization of marijuana, i.e. that it could be grown/ possessed in an established small amount for personal use. Half of the surveyed students (54\%), including 74\% of smokers, support the partial legalization of marijuana. $78 \%$ of the students are convinced about the medicinal properties of marijuana (Table III.).

About $6 \%$ of all the respondents used other drugs in addition to marijuana. $3 \%$ of all the respondents have used amphetamines, LSD and ecstasy at least once in their lifetime. The proportion of drug users was higher among students who smoked cigarettes than among non-smokers (Table III.).

The overwhelming majority ( $93 \%$ ) of the respondents believe that the way parents/guardians bring up children has an effect on whether a child takes or will take drugs. According to the respondents, this relationship may have a strong ( $46 \%$ of positive answers) or an indirect effect ( $47 \%$ of positive answers) (Table III.). razy (28\%), więcej niż kilka razy (11\%) lub tylko jeden raz - 7\% (Tab. III.).

Pośród ankietowanych 49\% uważa, że marihuana jest używką jak alkohol czy papierosy, natomiast 35\% pytanych twierdzi, że jest narkotykiem szkodliwym jak inne. 74\% ogółu ankietowanych jest świadomych konsekwencji prawnych wynikających z posiadania lub obrotu marihuaną w Polsce. Ta świadomość jest wyższa wśród osób palących niż niepalących ( $86 \%$ vs $71 \%$ ). Ponad połowa ankietowanych studentów (52\%) jest zwolennikiem legalizacji marihuany. Wśród nich przeważają osoby palące papierosy (72\%). $23 \%$ ankietowanej populacji nie popiera takich działań lub nie ma zdania w tym temacie. $12 \%$ ankietowanych jest przeciwnych częściowej legalizacji marihuany, tzn. aby mogła być ona uprawiana/posiadana w ustalonej niewielkiej ilości na własny użytek. Za częściową legalizacją marihuany opowiada się połowa ankietowanych studentów (54\%), w tym $74 \%$ palących. O właściwościach leczniczych marihuany jest przekonanych $78 \%$ studentów (Tab. III.)

Około $6 \%$ ogółu ankietowanych poza marihuaną używało także innych narkotyków. 3\% ogółu ankietowanych przynajmniej raz w życiu używało amfetaminy, LSD i ekstazy. Odsetek używających narkotyków był wyższy wśród studentów palących papierosy niż niepalących (Tab. III). 


\section{DISCUSSION}

In recent times, drugs have been the greatest threat to young people, and even children. Every year, more and more young people use psychoactive substances. Early age addiction has many health, psychological and economic consequences.

It is common among young people addicted to psychoactive substances to use several drugs simultaneously (e.g. marijuana and amphetamines). Alcohol and cigarettes are most commonly consumed, followed by marijuana (25).

The students are a specific group. The beginning of studies is often associated with changing the place of residence, weakening family ties, making new friends, participating in cultural events and social meetings. This is conducive to experimenting and reaching for stimulants.

Slightly fewer $(17.75 \%)$ students of the Medical University in Wrocław, compared to own results $(22 \%)$, admitted to be smokers (16). The highest percentage of the respondents (46\%) smoked up to 5 cigarettes a day (16). In the obtained results, this number of cigarettes was smoked by $90 \%$ of smokers. Kurpas et al. (16) confirmed the correlation between smoking and gender - males were significantly more often smokers $(p<0.001)$, and age - older students were more often smokers $(\mathrm{p}=0.035)$.

The research from the area of Kosovo shows that in the age group of 15-24 years, the smoking rate was $16.0 \%$, whereas in the age group of 25-34 years, it increased by almost $100 \%$ to a value of $31.9 \%$. In subsequent age groups, it gradually decreased. The smoking rate was higher among men (37.4\%) compared to women (19.7\%) (26).

A number of factors may be related to smoking, and these are gender, household status, and parental education (26).

The influence of gender on the popularity of cigarette smoking varies. The results of research from Morocco indicate that young men are significantly more likely to smoke than women $(26,27)$. On the other hand, research conducted on Brazilian youth did not show that boys smoked cigarettes significantly more than girls $(\mathrm{p}=0.52)$ (25). A similar lack of correlation was obtained in our study - the share of smoking men and women was comparable ( $23 \%$ of men and $21 \%$ of women smoked). Geographical conditions have an effect on the style of smoking. In European countries, the rate of female smokers is generally higher than in other regions of the world (28). In some cultures, the reason why female smokers constitute a minority among tobacco users is because smoking harms their image and reputation in society $(26,29)$.
Przeważająca większość (93\%) ankietowanych sądzi, że sposób wychowywania przez rodziców/opiekunów ma wpływ na to, czy dziecko bierze lub będzie brało narkotyki. Wg. ankietowanych ta relacja może mieć wpływ zdecydowany ( $46 \%$ twierdzących odpowiedzi) lub pośredni (47\% twierdzących odpowiedzi) (Tab. III.).

\section{DYSKUSJA}

W ostatnich czasach największym zagrożeniem dla młodzieży, a nawet dzieci są narkotyki. Z roku na rok coraz więcej młodych osób sięga po substancje psychoaktywne. Uzależnienie w młodym wieku niesie ze sobą wiele skutków, zarówno zdrowotnych, psychicznych, a także ekonomicznych.

Powszechne wśród osób młodych używających substancji psychoaktywnych, jest jednoczesne przyjmowanie kilku środków (np. marihuana i amfetamina). Najczęściej spożywany jest alkohol i papierosy, następnie marihuana (25).

Studenci są specyficzną grupą. Rozpoczęcie studiów często wiąże się ze zmianą miejsca zamieszkania, osłabieniem więzi rodzinnych, nawiązywaniem nowych znajomości, aktywnym uczestnictwem w imprezach kulturalnych i spotkaniach towarzyskich. Sprzyja to eksperymentowaniu i sięganiu po używki.

Nieznacznie mniej (17,75\%) studentów Uniwersytetu Medycznego we Wrocławiu w porównaniu z wynikami własnymi (22\%) przyznało się do palenia tytoniu (16). Największy odsetek badanych (46\%) wypalał do 5 szt. papierosów w ciągu doby (16). W uzyskanych wynikach taką ilość wypalało 90\% palących. Kurpas et al. (16) potwierdzili korelacje pomiędzy paleniem papierosów i płcią, istotnie częściej palaczami byli mężczyźni $(p<0,001)$ oraz wiekiem - częściej palaczami byli starsi studenci $(\mathrm{p}=0,035)$.

Badania $\mathrm{z}$ terenu Kosowa pokazują, że w grupie wiekowej 15-24 lata częstość palenia wyniosła 16,0\%, natomiast w grupie wiekowej 25-34 lata wzrosła prawie o $100 \%$ do wartości $31,9 \%$. W kolejnych grupach wiekowych stopniowo spadała. Częstość palenia była większa wśród mężczyzn $(37,4 \%)$ w porównaniu z kobietami $(19,7 \%)(26)$.

Szereg czynników może być związanych z paleniem, takich jak wiek, płeć, stan gospodarstwa domowego i poziom wykształcenia rodziców (26).

Wpływ płci na popularność palenia papierosów jest różny. Wyniki badań z Maroka wskazują, że młodzi mężczyźni istotnie częściej są palaczami niż kobiety $(26,27)$. Natomiast badania młodzieży brazylijskiej nie wykazały, aby chłopcy istotnie częściej od dziewcząt palili papierosy $(p=0,52)(25)$. Podobny brak korelacji uzyskano w naszych badaniach - udział palących kobiet i mężczyzn był porównywalny (paliło $23 \%$ mężczyzn i $21 \%$ kobiet). Uwarunkowania geograficzne 
In New Zealand, there has been a decline in traditional tobacco smoking in the last 6 years among adolescents (14-15 years), but there is an increase in e-cigarette users (30). In the conducted research, approximately $33 \%$ of the students have tried e-cigarettes, which is more than the number of smokers - $22 \%$. There was a significant difference between men and women who smoked e-cigarettes $(p=0.0307)$.

Among the students of the Medical University of Lodz, $31.6 \%$ of women and $44.3 \%$ of men admitted that they were smoking at the time of the research. A greater percentage of heavy smokers were men, $34.4 \%$ of whom smoked from 16 up to 20 cigarettes. One-third of the students had tried to use stimulants in their lifetime, and over $80 \%$ of women and over $50 \%$ of men had had a history of exposure to hallucinogens, including marijuana, hashish, LSD, and hallucinogenic mushrooms. Hallucinogens were regularly used by $7.5 \%$ of men (31). Amphetamine followed. The percentage of students using drugs in our study was $6.2 \%$, there was a significant difference between smokers and nonsmokers $(\mathrm{p}=0.01468)$. As in the studies by Łaszek et al. (31), hallucinogens (ecstasy, LSD), and amphetamines were popular.

Compared to own research, a higher percentage of smokers was among students of Rzeszów universities $34 \%$ of them declared that they had smoked or smoked cigarettes (21). However, similarly to our research, more than half of the smokers $(57.7 \%)$ declared that they smoked an average of less than five cigarettes a day. $25.8 \%$ of the respondents stated that they smoked between 5 and 10 cigarettes on average, and only $1.8 \%$ of the respondents admitted that they smoked more than 20 cigarettes a day (32). Young people (11-23 years old) in the study by Zarrouq et al. (27) reported that they smoked an average of 6.5 cigarettes a day. The percentage of smokers in that study group was $9.1 \%$, while the average age at which they started smoking was 13.9 years.

The overwhelming majority of the students from Rzeszów universities (83.6\%) surveyed in 2014 declared that they had never taken drugs, the remaining group had contact (in the past or recently) with marijuana and amphetamines, mainly (33). Among the studied group of students of Silesian universities, $49 \%$ had had contact with marijuana, including $28 \%$ using it several times, $11 \%$ more than a few times, and $8 \%$ only once. The summary of the data shows that a much higher percentage of students have been exposed to marijuana in the current study (2020). The increase in this drug's popularity in recent years, mainly among young people (15-24 years old), is also reported in the literature data (24). The drug that was most popular after marijuana was amphetamine, both among the students from Rzeszów (33) and Silesia. The situation is different for mają wpływ na styl palenia papierosów. W krajach europejskich występuje generalnie wyższy wskaźnik palaczy płci żeńskiej w przeciwieństwie do innych rejonów świata (28). W niektórych kulturach powodem, dla którego kobiety palące stanowią mniejszość wśród użytkowników tytoniu jest to, że palenie szkodzi ich wizerunkowi i reputacji w społeczeństwie $(26,29)$.

W Nowej Zelandii obserwuje się spadek palenia tytoniu tradycyjnego w ciągu ostatnich 6 lat (2014-2019) wśród młodzieży (14-15 lat), jednak występuje wzrost liczby sięgających po e-papierosy (30). W przeprowadzonych badaniach ok. 33\% studentów próbowało e-papierosów, jest to więcej niż liczba osób palących - 22\%. Występowała istotność różnic pomiędzy kobietami i mężczyznami palącymi e-papierosy $(\mathrm{p}=0,0307)$.

Pośród łódzkich studentów Uniwersytetu Medycznego do palenia tytoniu w chwili badania przyznało się $31,6 \%$ kobiet i 44,3\% mężczyzn. Większy odsetek palących nałogowo stanowili mężczyźni, wśród których $34,4 \%$ wypalało od 16 do 20 papierosów. Jedna trzecia studentów kiedykolwiek próbowała używać środków pobudzających, a ponad $80 \%$ kobiet i ponad $50 \%$ mężczyzn miało w przeszłości kontakt $\mathrm{z}$ halucynogenami, do których zaliczyli marihuanę, haszysz, LSD i grzyby halucynogenne. Srodki halucynogenne regularnie stosowało 7,5\% mężczyzn (31). Na kolejnym miejscu była amfetamina. Odsetek studentów używających narkotyków w naszych badaniach wynosił $6,2 \%$, występowała istotność różnic między palącymi i niepalącymi tytoń $(\mathrm{p}=0,01468)$. Popularne były, podobnie jak w badaniach Łaszek et al. (31), środki halucynogenne (ekstazy, LSD) oraz amfetamina.

Większy udział procentowy palaczy, w porównaniu z własnymi badaniami był wśród studentów rzeszowskich uczelni - $34 \%$ z nich zadeklarowało, że paliło lub pali papierosy (21). Natomiast podobnie jak w naszych badaniach, ponad połowa z palących $(57,7 \%)$ deklarowała, że wypalała przeciętnie poniżej pięciu papierosów dziennie. $25,8 \%$ ankietowanych twierdziło, że pali średnio od 5 do 10 papierosów, a jedynie 1,8\% respondentów przyznało, że wypala powyżej 20 papierosów dziennie (32). Młode osoby (11-23 lat) w badaniach Zarrouq et al. (27) podawały, że wypalały średnio 6,5 papierosa na dzień. Odsetek palących osób w tej grupie badanej wynosił $9,1 \%$, natomiast przeciętny wiek, w którym zaczynali palić wynosił 13,9 lat.

Przeważająca większość ankietowanych w 2014 r. studentów uczelni rzeszowskich $(83,6 \%)$ deklarowała, że nigdy nie brała narkotyków, pozostała grupa miała kontakt (kiedyś lub obecnie) przede wszystkim z marihuaną i amfetaminą (33). Pośród badanej grupy studentów śląskich uczelni $49 \%$ miało kontakt z marihuaną, w tym $28 \%$ używało jej kilka razy, $11 \%$ - więcej niż kilka razy a $8 \%$ tylko jeden raz. Zestawienie tych danych ukazuje, że w bieżących badaniach (2020 r.) znacznie 
legal highs (New Psychoactive Substances - NPS), the popularity of which has decreased over the years (2014 and 2020). In 2014, 10.7\% of the students from Rzeszów (33) tried legal highs, while in 2020 it was a small group $(1.5 \%)$ of our respondents.

The main reasons for using drugs by the students of Rzeszów universities were curiosity (67.2\%), lack of an attractive way of spending free time $(16.4 \%)$, boredom $(14.9 \%)$, having fun $(12.1 \%)$, escaping from problems $(11.9 \%)$, as well as peer pressure $(7.5 \%)$ (33). The students we surveyed most often mentioned curiosity as the reason to smoke their first cigarette. As in the studies by Kruk et al. (33), peer pressure contributed to initiation of tobacco smoking the least. Only 3\% of our respondents were persuaded by other people. In the light of the obtained answers, exposure to tobacco smoke at home (smoking by parents/guardians) did not bring significant consequences in the form of addiction in children. A similar number of students who smoke nowadays increased both in the presence of tobacco smoke (42\%) and in conditions of no exposure (58\%). Whereas, in the opinion of the respondents, the family environment influences the use of other psychoactive substances. Less than $7 \%$ of the students believe that upbringing has no influence on drug use. However, the supporting role of the environment in the fight against addiction is considered important. Relatives' support was the most helpful factor when quitting smoking (32).

In the light of the obtained research results, the coexistence of other addictions is of great importance in reaching for psychoactive substances. 33\% of student smokers used alternative forms of smoking - mainly electronic cigarettes and water pipe. Among Moroccans, hookah use was more widespread, on average around $70 \%$ (27). In our research, cigarette substitutes proved to be more popular among women than men. The recently limited availability of menthol cigarettes in Poland and the traditional products that are still on the market, indicated by global organizations as a factor that reduces smoking, may attract young people (especially girls) to modern tobacco products with milder tastes and aromas (34-38). Slim and scented cigarettes are more attractive, they are equated with a nice and pleasant luxury.

Cigarettes smoking promotes the use of marijuana as well as other drugs. Only $19 \%$ of the surveyed student smokers had never smoked marijuana in their lifetime. Among non-smokers, this percentage was three times higher $-60 \%$. It has been observed that student smokers are the main group of users of other psychoactive substances. The significance of the differences is especially visible among the respondents who used cannabis $(p=0.0364)$. Research conducted in other countries also show significant correlations between cigarette smoking and the popularity of the use of other psychoactive substances by adolescents $(25,27)$. większy odsetek studentów miał kontakt z marihuaną. O wzroście popularności tego narkotyku na przestrzeni ostatnich lat, głównie wśród młodych osób (15-24 lat), informują także dane literaturowe (24). Narkotykiem o największej popularności po marihuanie była amfetamina, zarówno wśród studentów rzeszowskich (33) jak i śląskich. Odwrotnie natomiast sytuacja wygląda w przypadku dopalaczy (nowe substancje psychoaktywne - NPS), których popularność spadła w ciągu zestawionych lat (2014 i 2020). W 2014 r. dopalaczy próbowało $10,7 \%$ studentów rzeszowskich (33) podczas, gdy w $2020 \mathrm{r}$ niewielka grupa $(1,5 \%)$ naszych ankietowanych.

Głównym powodem sięgania po narkotyki przez studentów rzeszowskich uczelni były: ciekawość $(67,2 \%)$, brak atrakcyjnego sposobu spędzania wolnego czasu $(16,4 \%)$, nuda $(14,9 \%)$, zabawa $(12,1 \%)$, ucieczka od problemów $(11,9 \%)$ a także presja kolegów (7,5\%) (33). Ankietowani przez nas studenci także najczęściej wymieniali ciekawość jako powód do zapalenia pierwszego papierosa. Podobnie jak w badaniach Kruk et al. (33) najmniejszy udział w inicjacji palenia tytoniu miała presja innych osób. Tylko 3\% naszych ankietowanych uległo namowie innych osób. W świetle uzyskanych odpowiedzi, narażenie na dym tytoniowy w domu (palenie papierosów przez rodziców/ opiekunów) nie przyniosło znaczących konsekwencji w postaci nałogu u dzieci. Podobna liczba palących obecnie studentów wzrastała zarówno w obecności dymu tytoniowego (42\%), jak i w warunkach braku narażenia (58\%). Natomiast środowisko rodzinne, w opinii respondentów, ma wpływ na używanie innych substancji psychoaktywnych. Niespełna 7\% studentów jest zdania, że wychowanie nie ma wpływu na używanie narkotyków. Dostrzegana jest natomiast wspierająca rola otoczenia w walce z nałogiem. Czynnikiem najbardziej pomocnym w rzucaniu palenia było wsparcie bliskich osób (32).

W świetle uzyskanych wyników badań duże znaczenie w sięganiu po środki psychoaktywne ma współwystępowanie innych nałogów. 33\% palących studentów używało alternatywnych form palenia tytoniu - głównie wymieniane były papierosy elektroniczne i fajka wodna. Pośród Marokańczyków używanie fajki wodnej było bardziej rozpowszechnione, średnio ok. 70 $\%$ (27). W naszych badaniach zamienniki papierosów okazały się popularniejsze wśród kobiet niż mężczyzn. Ograniczenie w ostatnim czasie w Polsce dostępności papierosów mentolowych i pozostawienie na rynku wyrobów tradycyjnych, typowane przez organizacje światowe jako czynnik zmniejszający palenie mogą pociągać młode osoby (w szczególności dziewczęta) do łagodniejszych smakowo i zapachowo nowoczesnych wyrobów tytoniowych (34-38). Papierosy typu slim 
In the surveys, young people provide comprehensive knowledge related to the dangers of drug use (23). In our research, smokers reported full $(100 \%)$ awareness of the consequences of long-term smoking. They had the knowledge that taking a single dose of drugs could turn into addiction. They made affirmative opinions about the addictive properties of marijuana. In the light of these results, it is interesting that the surveyed students are relatively easily inclined to "experiment" with various psychoactive substances, mainly to find themselves in a "different reality" or "relax".

According to the research by Rogowska (39), about half of Polish students have taken a drug at least once in their lifetime, and every third student is currently using intoxicants. As in this research, the students mainly used cannabis (marijuana or hashish) $42 \%$, and then amphetamines - $8 \%$. The availability of drugs translates into the popularity of their use. Among female students in India, the frequency of single use of psychoactive substances was $13.6 \%$, and $5.8 \%$ of respondents admitted to regular consumption (40). Rogowska (39) noticed that students from rural areas use psychoactive substances to a lesser extent than residents of large agglomerations (39).

In the light of the obtained research results, the students' high awareness of the health hazards and legal consequences of psychoactive substances does not translate into their behaviour. Although more than half (65\%) of the student smokers intend to quit in the future, almost $40 \%$ of men do not. $52 \%$ of the general student population and $72 \%$ of smokers support legalization of marijuana. The differences between smokers and non-smokers in terms of legalization are statistically significant. Even more of the surveyed students (54\%) support partial (for personal use) legalization of marijuana.

\section{CONCLUSIONS}

The conducted research shows that there were no differences in the frequency of using tobacco and other psychoactive substances depending on the field of study (medical and non-medical faculties). A comparable number of men and women admitted to the addiction of smoking. In terms of the obtained research results, it is indicated that the consumption of psychoactive substances by the surveyed students of Silesian universities is influenced by the addiction to smoking. Student smokers are also users of other psychoactive substances. In the surveys, half of them declared the use of marijuana, and $6 \%$ of other drugs. Among drugs, hallucinogens (LSD, ecstasy) and amphetamines were the most popular. One-third of the surveyed student smokers additionally used alternative forms of nicotine such as e-cigarettes and water pipes. Perhaps, the oraz zapachowe są bardziej atrakcyjne, są utożsamiane z miłym i przyjemnym luksusem.

Palenie papierosów sprzyja używaniu marihuany, a także innych narkotyków. Tylko 19\% spośród ankietowanych palących studentów nigdy w życiu nie paliła marihuany. Wśród osób niepalących odsetek ten wynosił trzykrotnie więcej - 60\%. Zaobserwowano, że studenci palący to główna grupa użytkowników innych substancji o działaniu psychoaktywnym. Istotność różnic jest szczególnie widoczna wśród badanych osób sięgających po marihuanę $(p=0,0364)$. Na istotne korelacje pomiędzy paleniem papierosów i popularnością używania innych środków psychoaktywnych przez młodzież wskazują także badania przeprowadzone w innych krajach $(25,27)$.

W ankietach młodzież zapewnia o kompleksowej wiedzy związanej z niebezpieczeństwem używania narkotyków (23). W naszych badaniach osoby palące informowały o pełnej (100\%) świadomości następstw długotrwałego palenia papierosów. Posiadali wiedzę, że przyjęcie jednokrotnej dawki narkotyków może przerodzić się w uzależnienie. Twierdząco wypowiadali się na temat właściwości uzależniających marihuany. W świetle tych wyników zastanawiający jest fakt, że ankietowani studenci stosunkowo łatwo skłaniają się do „eksperymentowania” z różnymi substancjami psychoaktywnymi, głównie po to, aby odnaleźć się w ,innej rzeczywistości” czy „wyluzować”.

Według badań Rogowskiej (39) około połowa polskich studentów użyła przynajmniej raz w życiu narkotyku, a co trzeci student aktualnie zażywa substancje odurzające. Podobnie jak w badaniach własnych studenci głównie sięgali po produkty pochodzące z konopi (marihuanę lub haszysz) $42 \%$, a następnie amfetaminę $8 \%$. Dostępność narkotyków przekłada się na popularność używania. Pośród studentek w Indiach częstość jednokrotnego zażycia substancji psychoaktywnych wynosiła $13,6 \%$, do regularnego spożycia przyznało się 5,8\% badanych (40). Rogowska (39) zauważyła, że studenci pochodzący ze wsi w mniejszym stopniu zażywają substancje psychoaktywne niż mieszkańcy dużych aglomeracji (39).

W świetle uzyskanych wyników badań wysoka świadomość studentów na temat szkodliwości zdrowotnych i konsekwencji prawnych środków psychoaktywnych, nie przekłada się na ich postępowanie. Chociaż ponad połowa (65\%) palących studentów w przyszłości zamierza rzucić palenie, to prawie $40 \%$ mężczyzn nie ma takiego zamiaru. 52\% ogólnej populacji studentów i 72\% spośród osób palących wypowiada się za legalizacją marihuany Różnice pomiędzy palącymi i niepalącymi tytoń w kwestii legalizacji są istotne statystycznie $(\mathrm{p}=0.0061)$. Jeszcze więcej badanych studentów $(54 \%)$ popiera częściową (na własny użytek) legalizację marihuany. 
propagated non-smoking trend has an impact on the declared relatively small amount of smoked cigarettes (a few cigarettes/day).

\section{REFERENCES}

1. Kondo T, Nakano Y, Adachi S, et al. Effects of tobacco smoking on cardiovascular disease. Circ J 2019; 83: 1980-1985. doi: 10.1253/circj.CJ-19-0323.

2. Herman M, Tarran R. E-cigarettes, nicotine, the lung and the brain: multi-level cascading pathophysiology. J Physiol 2020; 0,0: 1-9. doi: 10.1113/JP278388

3. Roco Á, Cerda B, Cayún JP, etal. Pharmacogenetics, tobacco, alcohol and its effect on the risk development cancer. Rev Chil Pediatr 2018; 89(4): 432-440. doi: 10.4067/S0370-41062018005000709.

4. Kilic DS, Kasap MY. Survey for describing students' smoking behavior. Procedia - Soc Behav Sci 2014; 116: 298-302. doi: 10.1016/j.sbspro.2014.01.211

5. Ekpu VU, Brown AK. The economic impact of smoking and of reducing smoking prevalence: review of evidence. Tob Use Ins. 2015; 14(8): 1-35. doi: 10.4137/TUI.S15628.

6. La Torre G, Saulle R, Unim B,et al. Knowledge, attitudes, and smoking behaviours among physicians specializing in public health: a multicentre study. Biomed Res Int 2014; 516734. doi: $10.1155 / 2014 / 516734$.

7. Menati W, Nazarzadeh M, Bidel Z, et al. Social and psychological predictors of initial cigarette smoking experience: a survey in male college students. Am J Mens Health 2016; 10(1): 14-23. doi: $10.1177 / 1557988314553262$.

8. Chang JT, Anic, GM, Rostron BL, et al. Cigarette smoking reduction and health risks: a systematic review and meta-analysis. Nicotine Tob Res 2020; ntaa156, https://doi.org/10.1093/ntr/ntaa156.

9. Shimatani $\mathrm{K}$, Ito $\mathrm{H}$, Matsuo $\mathrm{K}$, et al. Cumulative cigarette tar exposure and lung cancer risk among Japanese smokers. Jpn J Clin Oncol 2020; 50(9), 1009-1017. https://doi.org/10.1093/jjco/hyaa083

10. Jasielski P, Piędel F, Rocka A, et al. Smoking as a risk factor of onset and relapse of Multiple Sclerosis - a review. Neurol Neurochir Pol 2020; 54(3): 243-251. doi: 10.5603/PJNNS.a2020.0032.

11. Casado PL, Aguiar T, Fernandes Pinheiro MP, et al. Smoking as a risk factor for the development of periimplant diseases. Implant Dent 2019; 28(2): 120124. doi: 10.1097/ID.0000000000000876.

12. Akter S, Goto A, Mizoue T. Smoking and the risk of type 2 diabetes in Japan: A systematic review and meta-analysis. J Epidemiol 2017; 27(12): 553-561. doi: 10.1016/j.je.2016.12.017.

13. Gallo V, Vineis P, Cancellieri M, et al. Exploring causality of the association between smoking and

\section{WNIOSKI}

Z przeprowadzonych badań wynika, że nie występowały różnice $\mathrm{w}$ częstości sięgania po tytoń oraz inne substancje psychoaktywne w zależności od kierunku studiów (kierunki medyczne i niemedyczne). Do nałogu palenia przyznawała się porównywalna liczba kobiet i mężczyzn. W aspekcie uzyskanych wyników badań wskazuje się, że na zażywnie substancji psychoaktywnych przez ankietowanych studentów śląskich uczelni ma wpływ występowanie nałogu palenia tytoniu. Palący studenci to także użytkownicy innych substancji o działaniu psychoaktywnym. Połowa spośród nich deklarowała $\mathrm{w}$ ankietach używanie marihuany, a $6 \%$ innych narkotyków. Pośród narkotyków najpopularniejsze były środki halucynogenne (LSD, ekstazy) i amfetamina. Jedna trzecia badanych palących papierosy studentów dodatkowo korzystała $\mathrm{z}$ alternatywnych form używania nikotyny, były to e-papierosy i fajka wodna. Być może propagowany trend niepalenia ma wpływ na deklarowaną niewielką stosunkowo ilość wypalanych papierosów (kilka sztuk/ dobę).

Parkinson's disease. Int J Epidemiol. 2019; 48(3): 912-925. doi: 10.1093/ije/dyy230.

14. Bandiera S, Pulcinelli RR, Huf F, et al. Hepatic and renal damage by alcohol and cigarette smoking in rats. Toxicol Res 2020. https://doi.org/10.1007/ s43188-020-00057-y

15. Ferrante M, Saulle R, Ledda C, et al. Prevalence of smoking habits, attitudes, knowledge and beliefs among Health Professional School students: a crosssectional study. Ann Dell'istituto Superiore di Sanita 2013; 49(2): 143-149. DOI: 10.4415/ann_13_02_06

16. Kurpas D, Mroczek B, Bielska D, et al. Level of alcohol intake and tobacco smoking among students of Wroclaw Medical University. Probl Hig Epidemiol 2013; 94(4): 757-761.

17. WHO Report on the Global Tobacco Epidemic, 2019. Offer help to quit tobacco use. ISBN 97892-4-151620-4. Luxemburg. https://www.who.int/ tobacco/global_report/en/

18. Binkowska-Bury M, Sałacińska I, Więch P, et al. Palenie tytoniu wśród studentów pierwszego roku rzeszowskich uczelni. Med Og N Zdr 2015; 21(1), 101-106.

19. Kalupa W, Marcinkowski JT, Kara I, et al. Palenie tytoniu i zażywanie środków narkotycznych wśród studentów poznańskich uczelni - analiza porównawcza. Tobacco smoking and consumption of narcotics among students of Poznan universities - a comparative analysis. Probl Hig Epidemiol 2013; 94(4): 883-888.

20. Gashi S, Berisha M, Ramadani N, et al. Smoking behaviors in Kosova: results of STEPS survey. Zdr 
Varst 2017; 56(3): 158-165. Doi: 10.1515/sjph-20170021.

21. West R, Brown J, Jarvis M. Epidemic of youth nicotine addiction? What does the National Youth Tobacco Survey reveal about high school e-cigarette use in the USA? Qeios. 2019; ID: 745076.3 https:// doi.org/10.32388/745076.3

22. Sierakowski J. Używanie substancji psychoaktywnych Przez młodzież w 2019 r. Europejski program badań ankietowych w szkołach na temat używania alkoholu i narkotyków ESPAD.

23. Szpringer M, Wojciechowska M, Orczykowski $\mathrm{T}$. The use of the psychoactive substances by the lower-secondary school students from the Youth Educational Centre as the misinterpretation of the well-being. Zdrowie i dobrostan. Dobrostan i Społeczeństwo. 2015; 2(XXVI), 363-381.

24. Europejski raport narkotykowy na rok 2019. Tendencje i osiągnięcia. Europejskie Centrum Monitorowania Narkotyków i Narkomanii 2019. https://www.emcdda.europa.eu/system/files/ publications/11364/20191724_TDAT19001PLN_ PDF.pdf.

25. Andrade ME, Santos IHF, Souza AAM, et al. Experimentation with psychoactive substances by public school students. Rev Saude Publica 2017; 51: 82

26. Bendaou B, Zarrouq B, El Kinany K, et al. Risk factors and prevalence of use of different tobacco products among school adolescents in the North Central region of Morocco: a cross-sectional study. Pan Afr Med J 2018; 30: 73. doi:10.11604/ pamj.2018.30.73.10896.

27. Zarrouq B, Bendaou B, El Asri A, et al. Psychoactive substances use and associated factors among middle and high school students in the North Center of Morocco: a cross-sectional questionnaire survey. BMC Public Health 2016; 16: 468. DOI 10.1186/ s12889-016-3143-5

28. Maziak W, Mzayek F. Characterization of the smoking habit among high school students in Syria Eur J Epidemiol 2000;16(12): 1169-76. doi: 10.1023/a:1010907724688.

29. Bouaïti E, Mzouri M, Sbaï-Idrissi K, et al. Factors predictive of good motivation to quit smoking among Moroccan smokers attending a lung disease outpatient clinic in 2008. Rev Epidemiol Sante Publique 2010; 58(1): 68-73.

30. Walker N, Parag V, Wong SF, et al. Use of e-cigarettes and smoked tobacco in youth aged 1415 years in New Zealand: findings from repeated cross-sectional studies (2014-19). Lancet Public Health 2020; 5: e204-12.

31. Łaszek M, Nowacka E, Szatko F. Negatywne wzorce zachowań studentów. Część I. Konsumpcja alkoholu i stosowanie substancji psychoaktywnych. Negative behavior patterns of students. Part I. Consumption of alcohol and use of psychoactive substances. Probl Hig Epidemiol 2011; 92(1): 114-119

32. Kruk W, Hubert-Lutecka A, Zając K, et al. Palenie tytoniu przez studentów - skala problemu. Med Og Nauki o Zdr 2014; 20(4): 433-438.

33. Kruk W, Cichocka I, Zając K, et al. Problem of addictive substance use (legal highs, drugs, energy drinks) among students of selected Rzeszow universities. Probl Hig Epidemiol 2014; 95(4): 880-888

34. Soneji S, Barrington-Trimis JL, Wills TA, et al. Association between initial use of e-cigarettes and subsequent cigarette smoking among adolescents and young adults: a systematic review and metaanalysis. JAMA Pediatr 2017; 1;171(8):788-797. doi: 10.1001/jamapediatrics.2017.1488.

35. Fadus MC, Smith TT, Squeglia LM. The rise of e-cigarettes, pod mod devices, and JUUL among youth: Factors influencing use, health implications, and downstream effects. Drug Alcohol Depend 2019; 1;201: 85-93. doi: 10.1016/j.drugalcdep.2019.04.011.

36. Soneji SS, Knutzen KE, Villanti AC. Use of flavored e-cigarettes among adolescents, young adults, and older adults: findings from the population assessment for tobacco and health study. Public Health Rep 2019; 134(3): 282-292. doi:10.1177/0033354919830967.

37. Arane K, Goldman RD. Electronic cigarettes and adolescents. Can Fam Physician. 2016; 62(11): 897898.

38. Chyderiotis S, Spilka S, Beck F. Use of electronic cigarette in France among adolescents aged 17: Results from the ESCAPAD 2017 survey. Bull Cancer 2019; 106(12): 1132-1143. doi: 10.1016/j. bulcan.2019.06.016.

39. Rogowska AM. Prevalence of psychoactive substance use in college students. Probl Hig Epidemiol 2015; 96(1): 232-239.

40. Kaur R, Singh T, Basu D, et al. Prevalence and pattern of psychoactive substance use among female students aged 18-25 years in universities of North India. Int J Community Med Public Health 2019; 6(2): 602-609.

Received: 06.10.2020

Accepted for publication: 29.04.2021

Otrzymano: 06.10.2020 r.

Zaakceptowano do publikacji: 29.04.2021 r.

\section{Address for correspondence: Adres do korespondencji:}

Barbara Brodziak-Dopierała

Department of Toxicology and Bioanalysis

30 Ostrogórska Str.

41-200 Sosnowiec

e-mail: bbrodziak@sum.edu.pl 